SPORTIVE: Journal of Physical Education, Sport and Recreation
Volume 1 Nomor 2 Maret 2018
e-ISSN: $2597-7016$ dan p-ISSN: $2595-4055$
@) (1) This work is licensed under a Creative Commons Attribution
(c) International License

\title{
Analisis Manajemen Dinas Pendidikan Pemuda Dan Olahraga Dalam Meningkatkan Prestasi Olahraga di Kabupaten Ende
}

\section{Aschari Senjahari Rawe}

Keywords :

Analisis Manajemen; dan Prestasi Olahraga

\section{Corespondensi Author}

Universitas Flores

Email :

ayrakiranirawe@gmail.com

\section{Article History}

Received: 28-12-2017;

Reviewed: 10-01-2017;

Accepted: 25-02-2017;

Published: 18-03-2017

\begin{abstract}
Abstrak. Tujuan penelitian ini adalah untuk mengetahui gambaran, perencanaan, pengorganisasian, kepemimpinan,pelaksanaan, evaluasi dan pengawasan. Metode wawancara, dokumentasi, dan pengamatan. Hasil Penelitian adalah (1) Perencanaan Manajemen Dinas Pendidikan Pemuda dan Olahraga Kabupaten Ende sudah terlaksana dengan baik. (2) Penggorganisasian Manajemen Dinas Pendidikan Pemuda dan Olahraga Kabupaten Ende sudah terlaksana dengan baik. (3) Kepemimpinan Manajemen Dinas Pendidikan Pemuda dan Olahraga Kabupaten Ende sudah terlaksana dengan baik. (4) Pelaksanaan Manajemen Dinas Pendidikan Pemuda dan Olahraga Kabupaten Ende tidak terlaksana dengan baik. (5) Pengevaluasiaan dan Pengawasan manajemen olahraga prestasi belum berjalan dengan baik.hal tersebut terlihat bahwa belum terakomodasi dengan baik dalam satu bentuk berkas khususnya terencanaan dengan baik.
\end{abstract}

\section{PENDAHULUAN}

Dinamika olahraga prestasi yang terjadi di Kabupaten Ende tidak terlepas dari kebijakan pemerintah lewat peran Dinas Pendidikan Pemuda dan Olahraga kabupaten Ende - Flores Provinsi Nusa Tenggara Timur memang masih memerlukan pemberdayaan dalam pengertian olahraga prestasi menjadi wahana hanya sebagai "pelengkap". Organisasi di bidang olahraga lebih - lebih prestasi olahraga di hadapakan dengan kekurangan yang kronis yang terjadi di daerah kabupaten Ende - Flores Provinsi Nusa Tenggara Timur berupa persediaan infrastruktur yang kurang memadahi,perawatan sarana prasarana olahraga, kecilnya dana yang disediakan oleh pemerintah kabupaten Ende dan kesulitan lain adalah kekurangan tenaga administasi olahraga, pelatih, wasit, guru olahraga.

Sehingga pada saat mengikuti multi event seperti Pekan Olahraga Daerah Flores (PORDAFTA), Pekan Olahraga Daerah Nusa Tenggara Timur (PORDA), dan Pekan Olahraga Pelajar Daerah (POPDA), prestasi di seluruh cabang olahraga yang di ikuti oleh atlet yang mewakili Kabupaten Ende masih memperhatinkan, lewat pengumpulan medali yang di peroleh masing - masing cabang yang di pertandingkan. Berangkat dari observasi atau pengamatan bahwa minimnya prestasi olahraga dirasakan di daerah Kabupaten Ende Provinsi Nusa Tenggara Timur, akibatnya dari kurangnya perhatian pemerintah dari persoalan perencanaan sumber daya manusia yaitu .perekrutan tenaga administrasi olahraga, Pelatih, Guru,Wasit dilakukan oleh pemerintah daerah melalui Badan Kepegawaian Daerah (BKD) atas usulan dari Dinas Pendidikan Pemuda dan Olahraga, namun demikian jumlah yang di angkat menjadi pegawai negeri sipil tidak memadai bahkan dalam segi organisasi manajemen olahraga kualitas terkadang menjadi pertimbangan tersendiri sehingga prestasi olahraga di Kabupaten Ende tidak bersaing dengan daerah lain yang ada di Provinsi Nusa Tenggara Timur.

Dari segi sarana dan prasarana olahraga merupakan hal yang sangat fundamental dalam pelaksanaan olahraga, tanpa adanya fasilitas yang memadai maka atlet tidak mungkin 
tersalurkan bakatnya dalam latihan secara maksimal. Sejauh ini sarana prasarana yang dimiliki oleh pengurus maupun pelatih yang dipergunakan sangat minim serta tidak memenuhi standart / kualitas yang ada. Kenyataannya fasilitas, sarana prasarana yang dimiliki oleh pemerintah maupun cabang olahraga masih jauh dari kata memadai seperti kesedian stadion Marilonga, Lapangan Pancasila dan lapangan KONI Kabupaten Ende banyak tidak terurus perlu perawatan renowasi ulang dan ada yang diahlifungsikan.

Dari segi penyedian pendanaan olahraga lewat manajemen kepemimpinan dalam menentukan anggaran pemerintah daerah Kabupaten Ende dan Dewan Perwakilan Rakyat Daerah dalam menentukan, mengalokasikan anggaran pernah di bahas dalam sidang paripurna, tapi dalam kenyataan dana yang disediakan minim tidak sesuai dengan kebutuhan iven,kompetisi sehingga persiapan latihan dan mengikuti iven skala regional seperti Pekan Olahraga Daratan Flores ( PORDAFTA), Pekan Olahraga Daerah (PORDA) dan Pekan Olahraga Pelajar Daerah (POPDA) tidak dapat terlaksana dengan baik.

Dari segi Evaluasi dan pengawasan secara keseluruhan mulai dari perencanaan sampai akhir iven dalam laporan kegiatan yang diikuti iven regional Pekan Olahraga Daratan Flores (PORDAFTA), iven Pekan Olahraga Daerah (PORDA) dan Pekan Olahraga Pelajar Daerah (POPDA), tidak ada pertanggung jawaban transpransi persoalan dana yang dibutuhkan dan Evaluasi manajer, pelatih, atlet cabang olahraga yang di ikuti, seusai iven tidak dibahas dalam laporan dan evaluasi, sehingga pelaksanaan iven atau turnamen terkendala dalam mengikuti tahun - tahun yang akan datang.

\section{METODE}

Penelitian ini adalah penelitian deskriptif dengan metode kualitatif atau disebut penelitian deskriptif kualitatif, yaitu data yang muncul berupa kata - kata yang menggambarkan dan memaparkan keadaan subyek penelitian berdasarkan fakta yang tampak atau sebagaimana mestinya. Bogdam dan Taylor dalam Sugiyono (2014) mendefenisikan metodologi kualitatif sebagai prosedur penelitian yang menghasilkan data deskriptif berupa kata - kata tertulis atau lisan dari orang - orang dan pelaku yang dapat diamati. Lokasi penelitian ini dilaksanakan di Dinas Pendidikan Pemuda dan Olahraga di Kabupaten Ende Provinsi Nusa Tenggara Timur.

Instrumen penelitian yang digunakan dalam penelitian ini yaitu: observasi, pedoman wawancara (metode wawancara/interview), dokumentasi. Menurut Sutopo (2006 : 9) metode pengumpulan data dalam penelitian kualitatif secara umum dikelompokkan ke dalam dua jenis cara, yaitu teknis yang bersifat interaktif dan non interaktif.metode interaktif meliputi interview dan observasi berperan serta,sedangkan metode noninteraktif meliputi observasi takberperan serta, teknik kuisioner, mencatat dokumen, dan partisipasi tidak berperan.

Peneltian ini adalah penelitian deskriptif kualitatif. Pada peneltian kualitatif data yang muncul berupa kata - kata dan bukan rangkaian angka. Data yang berupa kata - kata tersebut masih sangat beragam, sehingga perlu diolah agar menjadi sistimatis, ringkas, dan logis.

Menurut Bogman dan Bikmen dalam Moeng ( 2007 : 249), mengemukakan bahwa analisis data kualitatif adalah upaya yang dilakukan dengan jalan bekerja dengan data, mengorganisasikan data, memilah - milahnya menjadi satuan yang dapat dikelola, mensintesiskannya, mencari dan menemukan pola, menemukan apa yang penting dan apa yang dipelajari, dan memutuskan apa yang dapat diceritakan kepada orang lain.

Dari definisi - definisi tersebut dapat disimpulkan bahwa analisa data kualitatif adalah proses pengorganisasian data - data yang diperoleh dari lapangan,mempelajarinya dan selanjutnya dipilah - pilah sehingga dapat dikelolah dan digali kembali informasi informasi penting yang dapat diperoleh dan akhirnya data - data tersebut dapat disajikan secara baik dalam urutan yang sistematik dan logis berdasarkan fakta - fakta dari lapangan dan sama sekali tidak dimaksudkan untuk membuktikan suatu prediksi atau hipotesis penelitian yang dapat menyebabkan penarikan kesimpulan yang keliru.

\section{HASIL DAN PEMBAHASAN}

Manajemen Bidang Keolahragaan Dinas Pendidikan Pemuda dan Olahraga di Kabupaten Ende Provinsi Nusa Tenggara Timur yang 
terdiri dari perencanaan, penggorganisasian, kepemimpinan pelaksanaan, pengawasan dan evaluasi yang diperoleh dalam penelitian ini.

Analisis Hasil Penelitian Pada bagian ini akan diuraikan hasil penelitian yang didapatkan penulis selama melakukan penelitian di Kabupaten Ende. Dengan ini saya menguraikan tentang Manajemen Dinas Pendidikan Pemuda dan Olahraga, dalam meningkatkan prestasi olahraga di Kabupaten Ende, Manajemen yang dimaksud dengan fokus penelitian ini yaitu Perencanaan, Pengorganisasian, Kepemimpinan, Pelaksanaan, Evaluasi dan Pengawasan.

Tabel 1. Perolehan Mendali PORDAFTA Setiap Kabupaten di Provinsi NTT

\begin{tabular}{lccccc} 
No & Nama Kabupaten & Emas & Perak & Perunggu & Total \\
1 & Sikka & 54 & 42 & 69 & 165 \\
2 & Ende & 34 & 36 & 57 & 127 \\
3 & Manggarai & 22 & 32 & 40 & 94 \\
4 & Ngada & 22 & 15 & 28 & 65 \\
5 & . Manggarai Barat & 22 & 14 & 20 & 56 \\
6 & Flores Timur & 20 & 23 & 33 & 76 \\
7 & Nagekeo & 11 & 12 & 29 & 52 \\
8 & Manggarai Timur & 6 & 9 & 11 & 26 \\
9 & Lembata & 4 & 16 & 30 & 50 \\
\hline
\end{tabular}

Sumber Data Bidang Pemuda dan Olahraga Kabupaten Ende Tahun 2016

Dalam upaya pencapaian prestasi yang maksimal maka dibutuhkan upaya - upaya yang dilakukan secara terencana dan berkesinambungan termasuk melakukan terobosan atau inovasi dalam bentuk latihan yang dilakukan secara efektif dan efisien. Dinas Pendidikan Pemuda dan Olahraga sebagai salah satu wadah pembinaan potensi prestasi para atlet berbakat terus berbenah dan mengembangkan bentuk - bentuk pembinaan sesuai dengan kebutuhan sehingga mampu menghasilkan atlet - atlet pelajar maupun pemuda yang berprestasi.

Pemerintah lewat Dinas Pemuda dan Olahraga Kabupaten Ende merupakan salah satu wada mewadahi pembinaan olahraga prestasi dan berbakat di Kabupaten Ende dan
Dalam menjalankan tugas dan fungsi kesatuan. di Dinas Pemuda dan Olahraga Kabupaten Ende didukung oleh 84 orang pegawai. Dan di bidang olahraga di dukung 6 orang pegawai sebagai berikut adalah data pegawai Bidang Pemuda dan Olahraga Kabupaten Ende Tahun 2016 urutan jabatan. sekitarnya., dengan kata lain bahwa para atlet yang dianggap telah mampu untuk bersaing pada level yang lebih tinggi kemudian dibina lebih lanjut, pada Dinas Pendidikan Pemuda dan Olahraga mengikuti latihan lanjutan dan berkompetisi pada iven resmi ataupun tidak resmi untuk mencapai kematangan atlet. Dalam perkembangannya atlet Kabupaten Ende mencetak atlet muda yang berkiprah dan menjadi harapan untuk perkembangan olahraga prestasi secara regional maupun nasional. Adapun beberapa pencapaian prestasi yang pernah dicapai dalam beberapa ivent regional, dan nasional yakni :

1) Pada Pekan Olahraga Pelajar Daerah (PORDAFTA) Tahun 2009, Sementara 
dalam laporannya, Ketua KONI Ende, Herman Rea menjelaskan perolehan medali yang berhasil dibawa pulang oleh kontingen Ende. Kontingen Ende yang membawa 260 peserta dengan mengikuti 12 cabang yakni atletik, tenis meja, taekwondo, kempo, karate, pencak silat, tenis lantai, tinju, bola kaki, bola voli, sepak takraw, bulu tangkis. Dari 12 cabang itu hasil yang diperoleh, atletik 3 Emas, 7 perak dan 5 perunggu. Tenis meja 5 emas, 2 perak, 1 perunggu, taekwondo 4 emas, 2 perak, 8 perunggu, kempo, 4 emas, 8 perak, 10 perunggu. Karate 7 emas, 7 perak, 17 perunggu, pencak silat 9 emas, 6 perak, 8 perunggu, tenis lantai 1 emas, 2 perak, tinju 1 emas, 2 perak, 4 perunggu. Sepak bola meraih medai perunggu, bola voli meraih perunggu, sepak takraw 2 perungu dan bulu tangkis 1.

2) Pada Olimpiade Olahraga Siswa Nasional (O2SN) Tingkat Regional Tahun 2008 yang diselenggarakan di Kupang berhasil meraih medali 4 Emas dan 3 Perak 4 Perunggu. Cabang atletik: nomor lempar turbo, Fransiskus/Densiana (Ende), Putri: Maria Mau (Ende), Gaya punggung 50 meter putra: Trisno Usman (Ende),). Putri, Maria Mau (Ende),. Gaya kupu- kupu putra, Trisno Usman (Ende),). Putri: Maria Mau (Ende). Karate putri: Katrina Beka (Ende). Pencaksilat putra: Ibnu Jalil Al Hanafi (Ende).

3) Pada Pekan Olahraga Pelajar daerah Tingkat Regional di ibu kota provinsi di Kupang Tekwondo emas 2 perak 3 perunggu 4 atlet 2 pencakilat 1 Emas, perak 3 perunggu 1 tinju 2 Emas 1 perak.

4) Taekwondo asal Kabupaten Ende atas nama Nadika Indah Rugeyah Tayeb dipercaya memperkuat NTT, di laga Pra PON pada November 2015 di Jakarta. Saat ini Nadika sedang menjalani pelatda di Kupang. Nadika turun di kelas bantam. Terpilihnya Nadika untuk memperkuat NTT dalam Prakualifikasi PON di Jakarta karena torehan prestasi yang diraih Nadika pada sejumlah kejuaraan tingkat Provinsi NTT.Prestasi yang pernah diraih Nadika, yakni tahun 2010 meraih medali perunggu pekan olahraga daerah (Porda). Prestasinya berlanjut saat menjadi atlet PPLP berhasil meraih medali emas di Kejuaraan PPLP. Hal sama terulang di Kejurda Taekwondo
POR Prov NTT November 2014 di Kupang berhasil meraih medali emas. Saat ini Nadika mengikuti seleksi pelatda Pra PON. Saat Open Turnamen Sumpah Pemuda di Jakarta, Nadika meraih medali perunggu. "Sederetan prestasi dibuat putri kabupaten Ende dipercaya mewakili NTT pada Pra PON November 2015 di Jakarta. prestasi yang dicatatkan oleh para Atlet Kabupaten Ende tentu merupakan pencapaian yang cukup membanggakan. Penting untuk diketahui bersama bahwa atlet yang saat ini berusia antara 12 sampai 22 tahun sebagian besar telah dibina sejak masih berusia 12 Tahun yang telah menorehkan prestasi seperti yang telah dicatatkan di atas dalam proses perkembangannya.

Namun yang terjadi belakangan ini prestasi atlet Kabupaten Ende secara menyeluruh cenderung menurun yang terlihat dari pencapaian yang diraih dalam beberapa tahun terakhir, baik itu prestasi secara tim maupun prestasi secara individual dalam berkontribusi terhadap kemajuan atlet di tingkat lokal, maupun regional. Hal ini dibenarkan oleh tim kepala bidang olahraga Kabupaten Ende, sehingga diperlukan perhatian khusus dalam menyikapi permasalahan ini. Menurut pengamatan di iven dalam beberapa tahun terakhir, salah satu yang menjadi penurunan prestasi atlet di Kabupaten Ende adalah kekurangan dana, sarana prasarana, sumber daya manusaia pada akhirnya akan bermuara pada pencapaian prestasi sebuah kabupaten Ende.

Berikut ini juga Tugas Pokok, Fungsi dan Rincian Tugas Bidang olahraga prestasi Pemerintah lewat Dinas Pemuda dan Olahraga Kabupaten Ende merupakan salah satu wada mewadahi pembinaan olahraga prestasi dan berbakat di Kabupaten Ende dan sekitarnya, untuk mengembangkan olahraga prestasi tidak terlepas dari peran Dinas Pendidikan Pemuda dan olahraga yaitu sebagai berikut :

\section{Tugas Pokok, Fungsi dan Rincian Tugas Kepala Bidang \\ Bidang Keolahragaan dipimpin oleh} Kepala Bidang, mempunyai tugas pokok melaksanakan pemberian pertimbangan, penyusunan, pelaksanaan, mengendalikan, dan pengawasan kebijakan, program dan kegiatan pada Bidang Keolahragaan yang meliputi 
olahraga pelajar dan mahasiswa, olahraga prestasi, dan olahraga rekreasi.

2. Kepala Bidang Keolahragaan mempunyai fungsi :

pelaksanaan, pembinaan dan pengembangan keolahragaan,penyiapan bahan perumusan kebijakan di bidang keolahragaan; penyusunan kebijakan teknis, standar, kriteria, dan pedoman serta pemberian bimbingan strategis pembinaan dan pengembangan keolahragaan; pelaksanaan kebijakan teknis bidang keolahragaan; Perencanaan pengorganisasian, Kepemimpinan, Pelaksanaan dan pengawasan pelaksanaan program dan kegiatan bidang keolahragaan, pelaksanaan pemassalan, pembibitan, dan pembinaan, olahraga pelajar mahasiswa, olahraga prestasi, dan olahraga rekreasi;pelaksanaan tugas kedinasan lain sesuai bidang tugasnya. Dengan perincian tugas sebagai berikut :

a) menyusun rencana kegiatan Bidang Keolahragaan sebagai pedoman dalam pelaksanaan tugas; mendistribusikan dan memberi petunjuk pelaksanaan tugas kepada bawahan sehingga pelaksanaan tugas berjalan lancar;memantau, mengawasi, dan mengevaluasi pelaksanaan tugas dan kegiatan bawahan untuk mengetahui tugas-tugas yang telah dan belum dilaksanakan;membuat konsep, mengoreksi, memaraf dan/atau menandatangani naskah dinas;mengikuti rapat-rapat sesuai dengan bidang tugasnya;melaksanakan perumusan bahan pertimbangan teknis kepada Kepala Dinas Pemuda dan Olahraga tentang penyelenggaraan, pembinaan dan pengembangan keolahragaan; menyusun konsep perumusan kebijakan Bidang Keolahragaan; melaksanakan penyusunan standar dan kriteria penyelengaraan serta kebijakan teknis pengembangan keolahragaan; melaksanakan penyusunan pedoman serta pemberian bimbingan strategis pembinaan dan pengembangan keolahragaan.

b) kebijakan teknis bidang keolahragaan;melaksanakan koordinasi, pengendalian, dan pengawasan pelaksanaan program dan kegiatan keolahragaan melaksanakan perumusan model dan strategi pemassalan, pembibitan, dan pembinaan, olahraga pelajar mahasiswa, olahraga prestasi, dan olahraga rekreasi;menyusun laporan hasil pelaksanaan tugas Bidang Keolahragaan dan memberikan saran pertimbangan kepada atasan sebagai bahan perumusan kebijakan; dan melaksanakan tugas kedinasan lain yang diperintahkan oleh atasan sesuai bidang tugasnya untuk mendukung kelancaran pelaksanaan tugas.

c) Tugas Pokok dan Rincian Tugas Kepala Seksi

1) Seksi Pembinaan Olahraga Pelajar dan Mahasiswa dipimpin oleh Kepala Seksi mempunyai tugas pokok melakukan pengawasan, pembinaan teknis dan pengembangan olahraga pelajar dan mahasiswa. Dengan perincian tugas sebagai berikut :

menyusun rencana kegiatan Seksi Pembinaan Olahraga Pelajar dan Mahasiswa sebagai pedoman dalam pelaksanaan tugas; mendistribusikan tugas-tugas tertentu dan memberi petunjuk pelaksanaan tugas kepada bawahan sehingga pelaksanaan tugas berjalan lancar; memantau, mengawasi, dan mengevaluasi pelaksanaan tugas dan kegiatan bawahan untuk mengetahui tugas-tugas yang telah dan belum dilaksanakan; membuat konsep, mengoreksi, memaraf dan/atau menandatangani naskah dinas; mengikuti rapat-rapat sesuai bidang tugasnya; melakukan penyusunan desain dan kerangka acuan teknis kegiatan pembinaan dan pengembangan olahraga pelajar dan mahasiswa; melakukan penyusunan panduan teknis penyelenggaraan, pembinaan, dan pengembangan olahraga pelajar dan mahasiswa melakukan koordinasi dalam rangka pembinaan dan pengembangan olahraga pelajar dan mahasiswa; melakukan penyusunan profil pembinaan dan proyeksi pengembangan olahraga pelajar dan mahasiswa; melakukan penelusuran bakat dan minat calon atlit dalam rangka pembibitan; memfasilitasi kegiatan olahraga usia dini, olahraga pelajar, dan olahraga mahasiswa; melakukan pembinaan pusat pendidikan dan latihan olahraga pelajar dan mahasiswa; menyusun laporan hasil pelaksanaan tugas Seksi Pembinaan Olahraga Pelajar dan Mahasiswa dan memberikan saran pertimbangan kepada atasan sebagai bahan perumusan kebijakan; dan melakukan tugas kedinasan lain yang diperintahkan oleh atasan sesuai bidang tugasnya untuk mendukung kelancaran pelaksanaan tugas. 
2). Seksi Pembinaan Olahraga

Prestasi dipimpin oleh Kepala Seksi mempunyai tugas pokok melakukan pengawasan, pembinaan teknis dan pengembangan olahraga prestasi.Dengan perincian tugas sebagai berikut :

a) menyusun rencana kegiatan Seksi Pembinaan Olahraga Prestasi sebagai pedoman dalam pelaksanaan tugas;mendistribusikan tugas-tugas tertentu dan memberi petunjuk pelaksanaan tugas kepada bawahan sehingga pelaksanaan tugas berjalan lancar;

b) memantau, mengawasi, dan mengevaluasi pelaksanaan tugas dan kegiatan bawahan untuk mengetahui tugas-tugas yang telah dan belum dilaksanakan;

c) membuat konsep, mengoreksi, memaraf dan/atau menandatangani naskah dinas; mengikuti rapat-rapat sesuai dengan bidang tugasnya;melakukan penyusunan desain dan kerangka acuan teknis serta rencana kerja pembinaan dan pengembangan prestasi olahraga;

d) melakukan fasilitasi pelaksanaan kegiatan pembinaan dan pengembangan prestasi olahraga;melakukan penelusuran bakat dan minat olahragawan dalam rangka peningkatan prestasi melakukan pemusatan dan pembinaan olahraga prestasi;melakukan kegiatan peningkatan wawasan, sikap dan keterampilan teknis bagi pembina, pelatih, dan wasit olahraga;

e) melakukan penyusunan bahan koordinasi dan pembinaan club-club olahraga prestasi;melakukan pembinaan, bimbingan teknis dan kompetisi berkala berbagai cabang olahraga; melakukan fasilitasi keikutsertaan atlet berprestasi dalam berbagai event kompetisi, baik pada tingkat nasional maupun internasional;

f) melakukan pengajuan usul pemberian penghargaan bagi olahragawan berprestasi; menyusun laporan hasil pelaksanaan tugas Seksi Pembinaan Olahraga Prestasi dan memberikan saran pertimbangan kepada atasan sebagai bahan perumusan kebijakan; dan melakukan tugas kedinasan lain yang diperintahkan oleh atasan sesuai bidang tugasnya untuk mendukung kelancaran pelaksanaan tugas.

3) Seksi Pembinaan Olahraga Rekreasi dipimpin oleh Kepala Seksi mempunyai tugas melakukan pengendalian, pengawasan, pembinaan dan pengembangan olahraga Rekreasi.Dengan perincian tugas sebagai berikut :

a) menyusun rencana kegiatan Seksi Pembinaan Olahraga Rekreasi sebagai pedoman dalam pelaksanaan tugas mendistribusikan tugas-tugas tertentu dan memberi petunjuk pelaksanaan tugas kepada bawahan sehingga pelaksanaan tugas berjalan lancar; memantau, mengawasi, dan mengevaluasi pelaksanaan tugas dan kegiatan bawahan untuk mengetahui tugastugas yang telah dan belum dilaksanakan membuat konsep, mengoreksi, memaraf dan/atau menandatangani naskah dinas mengikuti rapat-rapat sesuai dengan bidang tugasnya;

b) menyusun desain dan kerangka acuan teknis pembinaan olahraga rekreasi; melakukan fasilitasi pembentukan tim fasilitator penggerak pemassalan olahraga rekreasi melakukan pembinaan, bimbingan teknis dan pengembangan olahraga rekreasi bagi tim fasilitator penggerak pemassalan olahraga melakukan penggalian dan promosi pengembangan olahraga tradisional menyiapkan bahan koordinasi dan kerjasama dengan instansi terkait, organisasi olahraga dalam rangka pemasalahan olahraga rekreasi mengadakan festival olahraga rekreasi melakukan falisitasi peningkatan kapasitas pelatih dan wasit olahraga rekreasi melakukan fasilitasi peningkatan partisipasi masyarakat terhadap pengembangan olahraga rekreasi melakukan layanan administrasi dan penyusunan laporan kinerja seksi Pembinaan Olahraga Rekreasi menyusun laporan hasil pelaksanaan tugas Seksi Pembinaan Olahraga Rekreasi dan memberikan saran pertimbangan kepada atasan sebagai bahan perumusan kebijakan; dan melakukan tugas kedinasan lain yang diperintahkan oleh atasan sesuai bidang tugasnya untuk mendukung kelancaran pelaksanaan tugas.

Hasil wawancara tentang Perencanaan olahraga prestasi di Dinas Pendidikan Pemuda dan Olahraga kabupaten Ende. Dari segi perencanaan kita punya sumber daya manusia sebagian sudah ada kita akan terapkan pelatihan untuk pegawai admistrasi, pelatih, official, yang berkompeten untuk mengembangakan olahraga "Prestasi yang ada di kabupaten Ende sudah memasuki tingkat kestabilan yaitu pemerataan 
juara dari cabang yang dipertandingkan di Pekan olahraga Pelajar Daerah, Pekan Olahraga Daerah Provinsi Nusa Tenggara Timur, yang diikuti tetapi hal ini juga penyebabnya adalah bahwa dari Anisis SWOT. faktor Internal dan Eksternal dalam pelaksanaan olahraga prestasi pada Dinas Pendidikan dan Pemuda Olahraga sebagai berikut : Analisis Faktor Internal Dinas Pendidikan Pemuda dan Olahraga Kabupaten Ende yang mempengaruhi kinerja pelayanan berdasarkan telahan terhadap visi dan misi Bupati dan Wakil Bupati Kelemahan terbatasnya sarana dan prasarana pendukung di Dinas Pemuda dan Olahraga Kabupaten Ende. rendahnya anggaran yang disediakan untuk membiayai kegiatan pembinaan dan pengembangan bidang kepemudaan dan keolahragaan. Lemahnya sistem pembinaan dan pengelolaan kelembagaan pemuda dan olahraga.

Analisis Manajemen Dinas Pendidikan Pemuda dan Olahraga dalam Meningkatkan Olahraga Prestasi di Kabupaten Ende Provinsi Nusa Tenggara Timur. Dapat di lihat dari Perencanaan, Pengorganisasian, Kepemimpinan, Pelaksanaan, Evaluasi dan Pengawasan dalam meningkatkan Olahraga prestasi. Lebih jelasnya dapat dilihat pada pembahasan berikut ini.

\section{Perencanaan manajemen olahraga prestasi di Dinas Pendidikan Pemuda dan Olahraga Kabupaten Ende.}

Hasil penelitian sebagaimana yang digambarkan di atas menunjukan bahwa manajemen perencanaan olahrga prestasi di Dinas Pendidikan Pemuda dan Olahraga kabupaten Ende, sejalan dengan pendapat T.Hani Handoko (2013; 83). Sebelum para manajer dapat mengorganisasi, memimpin, atau mengendalikan, terlebih dahulu mereka harus membuat rencana yang memberikan arah pada setiap kegiatan organisasi. Pada tahap perencanaan para manajer menentukan apa yang akan dikerjakan, kapan akan mengerjakan, bagaimana mengerjakannya, dan siapa yang akan mengerjakannya.Kebutuhan akan perencanaan ada pada semua tingkatan manajemen dan semakin mengingkat pada tingkatan manajemen yang lebih tinggi, dimana perencanaan itu mempunyai kemungkinan dampak yang paling besar pada keberhasilan organisasi. Pada tingkatan top manajer pada umumnya mencurahkan hampir semua waktu perencanannya jauh ke masa depan dan pada strategi-strategi dari seluruh organisasi. Manajer pada tingkatan yang lebih rendah merencanakan terutama untuk sub unit mereka sendiri dan untuk jangka waktu yang lebih pendek.

Salah satu maksud dibuat perencanaan adalah melihat program-program yang dipergunakan untuk meningkatkan kemungkinan pencapain tujuantujuan di waktu yang akan datang, sehingga dapat meningkatkan pengambilan keputusn yang lebih baik. Oleh karena itu, perencanaan organisasi harus aktif, dinamis, berkesinambungan dan kreatif, sehingga manajemen tidak hanya bereaksi terhadap lingkungannya, tapi lebih menjadi peserta aktif dalam dunia usaha.

Ada dua alasan dasar perlunya perencanaan untuk mencapai "protective benefits" yang dihasilkan dari pengurangan kemungkinan terjadinya kesalahan dalam pembuatan keputusan. Untuk mencapai "positive benefits" dalam bentuk meningkatnya sukses pencapaian tujuan organisasi. Beberapa manfaat perencanaan menurut Hani Handoko (2013) Membantu manajemen untuk menyesuaikan diri dengan perubahan - perubahan lingkungan, Memungkinkan manajer memahami keseluruhan gambaran operasi lebih jelas, Membantu penempatan tanggung jawab lebih tepat,Memberikan cara pemberian perintah untuk beroperasi, Memudahkan dalam melakukan koordinasi di antara berbagai bagian organisasi, Membuat tujuan lebih khusus, terperinci dan lebih mudah dipahami ,Meminimumkan pekerjaan yang tidak pasti, Menghemat waktu, usaha, dan dana. Terdapat pula beberapa variasi dalam tanggung jawab perencanaan yang tergantung pada ukuran dan tujuan organisasi dan pada fungsi atau kegiatan khusus manajer. Organisasi yang besar dan berskala internasional lebih menaruh perhatian pada perencanaan jangka panjang daripada perusahaan lokal. Akan tetapi pada umumnya organisasi perlu mempertimbangkan keseimbangan antara perencanaan jangka panjang maupun perencnaan jangka pendek. Karena itu penting bagi para mnajer untuk mengerti peranan perencanaan secara keseluruhan.

Tentang Manajemen Perencanaan tujuan setiap rencana adalah untuk membantu sumber daya - sumber daya dalam kontribusinya secara positif terhadap pencapaian tujuan dan sasaran 
organisasi. Rencana - rencana yang harus dibuat untuk mencapai tujuan - tujuan organisasi sebelum para manajer dapat menentukan hubungan - hubungan organisasi, kualifikasi personalia yang dibutuhkan, bagaimana bawahan diarahkan.

Unsur - unsur rencana, dalam wujud anggaran, program, prosedur kebijaksanaan, dan sebagainya. Perencanaan, meliputi berbagai tingkatan dan setiap tingkatan merupakan bagian dari tingkatan yang lebih tinggi. Perencanaan ini berhubungan dengan kegiatan - kegiatan yang dilaksanakan, seperti program pengiklanan, prosedur seleksi personalia,anggaran penelitian dan pengembangan dan seterusnya. Dalam suatu organisasi rencana diperincikan melalui tingkatan - tingkatan yang membentuk hirarki dan paralcl dengan struktur organisasi. Pada setiap tingkatan, rencana mempunyai dua fungsi :menyediakan peralatan untuk pencapaian serangkaian sasaran dari,rencana tingkatan diatasnya, dan sebaliknya menunjukan sasaran yang harus dipenuhi rencana tingkatan di bawahanya. Rencana dari manajemn puncak akan dibuat menjadi rencana - rencana yang lebih terperinci oleh satuan satuan manajemen menengah dan lini pertama.

Konsep Dasar Perencanaan terutama yang menyangkut pengertian merupakan langkah yang strategis di dalam menguasai konsep-konsep serta indikator-indikator dari perencanaan itu sendiri. Perencanaan merupakan proses karya yang berkesinambungan sampai pada tahap pelaksanaan dan bahkan sampai pada tahap evaluasi. Seorang perencana selalu berusaha mengorganisasikan sumber-sumber atau faktorfaktor, seperti orang, material, dana dalam proses pengerjaan suatu kegiatan. Perencanaan juga merupakan langkah kedua dalam pengelolaan kegiatan setelah mengidentifikasi masalah-masalah, baik dari hasil penelitian maupun dari pengumpulan data yang sederhana.

Kurangnya berfikir strategis dan tidak mantapnya perencanaan dalam kegiatan komunikasi akan menimbulkan kontroversi dari pada memecahkan masalah. Dalam perencanaan sering berkaitan dengan istilah goal dan objective di samping meliputi pendekatan-pendekatan dan strategi yang harus diadakan. Proses perencanaan melibatkan berbagai unsur di antaranya menurut Harold
Koontz adalah menentukan tujuan, menetapkan premis-premis serta mencari dan menyelidiki berbagai kemungkinan rangkaian tindakan yang diambil. Dalam penilaian tiap-tiap kemungkinan yang diselidiki berdasarkan pertimbangan untung rugi serta faktor-faktor yang akan mempengaruhi dalam pengambilan keputusan. Harus disadari bahwa perencanaan banyak menghadapi faktor-faktor yang tidak pasti dan berubah-ubah sehingga penilaian terhadap kemungkinan tersebut sangat sulit untuk dilakukan.

Berdasarkan hasil wawancara dan pendapat para pakar ahli sesuai dengan fakta yang ada dilapangan menunjukan bahwa di bidang perencanaan yang dilakukan oleh pihak manajemen Bidang olahraga pada Dinas Pendidikan Pemuda dan Olahraga Kabupaten Ende Propinsi Nusa Tenggara Timur, sudah berjalan sesuai dengan tahapan-tahapan proses perencanaan. Hal ini dapat terlihat dengan adanya program-program yang jelas dan sesuai dengan tujuan yang ingin dicapai dengan hasil yang didapat,tetapi dalam menjalakan kegiatan perencanaan kerja kepanitian atatu mengikuti pertandingan skala regional masih ada kendala yaitu kurangnya sumber daya manusia, persoalan wasit, pelatih dan anggaran dana yang tidak mencukupi untuk kegiatan atau pertandingan tingkat kabupaten dan kota yang ada di provinsi Nusa Tenggara Timur oleh karena itu harapan dari berbagai pihak yang ada di Kabupaten Ende mereka mengiginkan Pemerintah daerah dan Dewan Perwakilan Rakyat daerah bisa mencari solusi jalan terbaik untuk mengembangkan olahraga prestasi sehingga bisa bersaing dengan daerah lain yang ada di Provinsi Nusa Tenggara Timur.

Dari pendapat saya dalam penelitian di Dinas Pendidikan Pemuda dan Olahraga Kabupaten Ende tentang perencanaan, dengan ini saya menyimpulkan dan membahas minor penelitian ini, dalam segi Perencanaan yang dilakukan oleh pihak manajemen Bidang olahraga sudah berjalan sesuai dengan tahapantahapan proses perencanaan. Hal ini dapat terlihat dengan adanya program-program yang jelas dan sesuai dengan tujuan yang ingin dicapai dengan hasil yang didapat, sehingga olahraga prestasi di Kabupaten Ende berjalan sesuai dengan harapan.

Peluang dan kelemahan tingginya dukungan pemerintah terhadap upaya peningkatan prestasi pemuda dan olahraga, 
meningkatnya kepercayaan masyarakat terhadap pelayanan pengembangan kepemudaan dan keolahragaan yang disajikan pemerintah, terbukanya peluang berprestasi melalui rutinitas kejuaraan bidang kepemudaan dan keolahragaan.

Tantangan dan kekuatan meningkatnya tuntutan masyarakat terhadap prestasi pemuda dan olahraga, meningkatnya persaingan prestasi tingkat regional dan nasional, tingginya tawaran pihak luar kepada pemuda dan pelaku olahraga untuk berprestasi di luar Kabupaten Ende, karena dari hasil yang ada olahraga prestasi yang sering menjuarai antara lain tinju dan beladiri maupun atletik kabupaten Ende ,meraup hasil yang lebih di andalkan, dari hal ini pemerintah kurang mendukung dari segi pendanaan, sarana prasarana dan sumberdaya manusia dalam persoalan Pelatih, wasit, dan tenaga administrasi.

\section{Pengorganisasian manajemen olahraga prestasi di Dinas Pendidikan Pemuda dan Olahraga Kabupaten Ende.}

Hasil penelitian menunjukan bahwa pengorganisasian manajemen di Dinas Pendidikan Pemuda dan Olahraga dalam Meningkatkan Olahraga Prestasi di Kabupaten Ende, Pengorganisasian yang dilakukan oleh Bidang Pemuda dan olahraga sudah berjalan sesuai dengan dasar-dasar organisasi. Hal ini dibuktikan dengan adanya struktur organisasi yang jelas dan dibedakan tugas dan kewajibannya.Walaupun pada dasarnya tugas dilakukan bersama-sama antara Kepala Bidang, kepala seksi dan staf pegawai dalam pelaksanaan olahraga prestasi. (1) Dalam pembentukan struktur organisasi dilibatkan semua pegawai pada bidang keolahragaan (2) anggota yang telah terbentuk dalam struktur bekerja sudah maksimal,terciptanya kekeluargaan antara personil sehingga terciptanya iklim organisasi secara dinamis dan berjalan sesuai dengan harapan.

Tetapi dalam pembentukan struktur organisasi,terhadap hubungan kerja lintas lembaga atau bidang tidak terlibat dalam kegiatan pertandingan dan iven tidak melibatkan bidang lain dalam Dinas Pendidikan Pemuda dan Olahraga Kabupaten Ende,komunikasi tetap dibangun,tetapi pada nuansa untuk kegiatan tidak terlibat banyak, hanyak guru - guru dari sekolah menjadi wasit dan pelatih dari instansi lain untuk meningkatkan prestasi olahraga di
Dinas Pendidikan Pemuda dan Olahraga kabupaten Ende Propinsi Nusa Tenggara Timur.

Dari hasil penelitian diatas menurut teori G.Hodges dalam Buku T.Hani Handoko (2013). menunjukan bahwa Pengorganisasian adalah langkah untuk menetapkan, menggolongkan dan mengatur berbagai macam kegiatan, menetapkan tugastugas pokok, wewenang dan pendelegasian wewenang oleh pimpinan kepada staf dalam rangka mencapai tujuan organisasi. Berdasarkan defenisi tersebut maka fungsi pengorganisasian merupakan alat untuk memadukan (sinkronisasi) dan mengatur semua kegiatan yang ada kaitannya dengan personil, finansial, materil dan tata cara untuk mencapai tujuan organisasi yang telah disepakati bersama. Tiang dasar pengorganisasian adalah prinsip pembagian kerja (division of labor). yang meemungkinkan sinergi terjadi.

Untuk mengembangkan fungsi pengorganisasian, seorang manajer dapat mengetahui pembagian tugas untuk perorangan dan kelompok,hubungan organisatoris antar manusia yang menjadi anggota dan staf sebuah organisasi,pendelegasian wewenang, serta pemanfaatan dan fasilitas fisik yang dimiliki organisasi. Kualifikasi personalia yang rendah digunakan dan latihan jabatan lebih mudah.Gerakan-gerakan dan perpindahan yang percuma dari komponen pekerjaan yang besar diminimumkan. Lebih dari itu,pembagian kerja mengarahkan penanaman pada peralatan dan mesin-mesin yang efisien untuk meningkatkan produktifitas. Namun apabila pembagian kerja dilakukan secara ekstrim maka akan menimbulkan kebosanan,keletihan,monoton dan kehilangan motivasi yang dapat menghasilkan ketidak efisienan dan bukan efisiensi.

Misi dan Tujuan Organisasi sebelum organisasi menentukan tujuan-tujuan, terlebih dahulu harus menetapkan misi ataumaksud organisasi. Misi adalah suatu pernyataan umum dan abadi tentang maksud organisasi. Misi suatu organisasi adalah maksud khas (unik) dan mendasar yangmembedakan organisasi dari organisasi-organisasi lainnya dan mengindentifikasikan ruanglingkup operasi dalam hal produk dan pasar. Misi merupakan perwujudan dasar filsafat para pembuat keputusan strategik perusahaan, mencerminkan konsep diri perusahaan, serta menunjukan bidang-bidang produk atau jasa pokok dan kebutuhan-kebutuhan langgananutama yang 
akan dipuaskan perusahaan.Tujuan organisasi ialah suatu pernyataan tentang keadaan yang diinginkan di manaorganisasi bermaksut untuk merealisasikan dan sebagai pernyataan tentang keadaan diwaktu yang akan datang di mana organisasi sebagai kolektifitas mencoba untuk menimbulkannya. Tujuan organisasi merupakan pernyataan tentang keadaan atau situasi yang tidak terdapat sekarang tetapi dimaksudkan untuk dicapai di waktu yang akan datangmelalui kegiatan-kegiatan organisasi.

Efisiensi aliran pekerjaan tergantung pada keberhasilan integrasi satuan satuan yang bermacam-macam dalam organisasi. Pembagian kerja dan kombinasi tugas seharusnya mengarah ke tercapainya struktur-struktur departemen dan satuan-satuan kerja. Cara dimana organisasi dapat memutuskan pola organisasi yang akan digunakan untuk mengelompokkan kegiatankegiatan yang bermacam-macam untuk dilaksanakan. Beberapa bentuk departementalisasi yang akan dibicarakan berikut ini adalah atas dasar fungsi,produk atau jasa,wilayah,langganan,proses atau peralatan waktu, pelayanan alpha numerical,proyek dan matriks.

a. Departementalisasi Fungsional

Departementalisasi

fungsional mengelompokkan fungsi-fungsi yang sama atau kegiatan-kegiatan sejenis untuk membentuk suatu satuan organisasi. Semua individu yang melaksanakan fungsi yang sama di kelompokkan bersama,seperti seluruh personalia penjualan,akutansi,programmer computer dan sebagainya.

Kebaikan utama pendekatan fungsional adalah bahwa pendekatan ini menjaga kekuasaan dan kedudukan fungsifungsi utama,menciptakan efisiensi melalui spesialisasi,memusatkan keahlian organisasi dan memungkinkan pengawasan manjemen puncak lebih ketat terhadap fungsi-fungsi. Pendekatan ini cocok untuk lingkungan yang stabil serta memerlukan koordinasi internal yang minimum,membutuhkan lebih sedikit keterampilan dasar pribadi dan duplikasi personalia dan peralatan dari segi biaya.

Kelemahan struktur fungsional adalah struktur ini bisa menimbulkaan konflik antar fungsi-fungsi, menyebabkan kemacetankemacetan pelaksanaan tugas yang berurutan,memberikan tanggapan lebih lambat terhadap perubahan ,hanya memusatkan pada kepentingan tugas-tugasnya,dan menyebabkan para anggota berpandangan lebih sempit serta kurang inovatif.

b. Departementalisasi Divisional

Banyak perusahaan besar dengan banyak jenis produk,di organisasikan menurut struktur organisasi divisional. Bila departementalisasi perusahaan menjadi terlalu kompleks dan tidak praktis bagi struktur fungsional,manajer perlu membentuk divisidivisi semi otonomi diman setiap divisi merancang,memproduksi dan memasarkan produknya sendiri. Organisasi divisional dapat mengikuti pembagian divisi-divisi atas dasar produk,wlayah (geografi),langganan,dan proses atau peralatan. Struktur organisasi divisional atas dasar produk. Setiap departemen bertanggungjawab atas suatu produk atau sekumpulan produk adalah pola logik yang dapat diikuti bila jenis-jenis produk mempunyai tekhnologi pemrosesan dan metode-metode yang sangat berbeda satu dengan yang lain dalam organisasi.. mengelompokan fungsifungsi yang sama atau kegiatan-kegiatan sejenis untuk membentuk suatu satuan organisasi.

Kebaikan pendekatan visioanal adalah bahwa pendekatan ini menjaga kekuasaan dan kedudukan fungsi-fungsiutama, menciptakan efisiensi melalui spesialisasi, memusatkan keahlian organisasi, dan memungkinkan pengawasan manajemen puncak lebih ketat terhadap fungsi.Kelemahan struktur fungsional dapat menciptakan konflik antar fungsi-fungsi, menyebabkan kemacetan pelaksanaan tugas yang berurutan, memberikan tanggapan lebih lambat terhadap perubahan, hanya memusatkan pada kepentingan tugas-tugasnya, dan menyebabkan para anggota berpandangan lebih sempit serta kurang inovatif. Berdasarkan hasil wawancara, dan pendapat para pakar ahli sesuai dengan fakta yang ada dilapangan menunjukan bahwa di Pengorganisasian yang dilakukan oleh Bidang Pemuda dan olahraga Pada Dinas Pendidikan Pemuda dan Olahraga sudah berjalan sesuai dengan dasar-dasar organisasi. Hal ini dibuktikan dengan adanya struktur organisasi yang jelas dan dibedakan tugas dan kewajibannya. Walaupun pada dasarnya tugas dilakukan bersama-sama antara Kepala Bidang, kepala seksi dan staf pegawai tetapi hal ini tidak menjadi suatu kendala yang serius dalam pelaksanaan olahraga prestasi. Tapi yang dilihat di sini bahwa masih banyak kekurangan yaitu setiap kepala seksi tidak mempunyai stafnya 
yang menjalankan tugas,kepala seksi bekerja sendiri tampa bantuan staf,kemudian kedala lain dalam pembentuka panitian hanya di tunjuk orang tertentu,dan kurangnya sumberdaya manusia yaitu persoalan wasit dan pelatih olahraga prestasi.

Dari pendapat saya dalam penelitian di Dinas Pendidikan Pemuda dan olahraga Kabupaten Ende, tentang pengorganisasian saya menyimpulkan dan membahas Minor penelitian ini, bahwa dalam struktur organisasi perlu ditambahkanya wakil ketua Sekretaris membantu Kepala Bidang dan Kepala Seksi harus mempunyai sekretaris dan Staf Pegawainya supaya lebih meringankan kinerja dari Kepala Bidang dan Kepala Seksi, karena tugas seorang kepala sangatlah banyak. Apa bila ada tugas luar. Dengan itu garis koordinasi akan tetap berjalan, kemudian dalam pelaksanaan harus adanya sumber daya manusia untuk memenuhi standar kualifikasi olahraga prestasi.

\section{Kepemimpinan Manajemen Olahraga Prestasi Di Dinas Pendidikan Pemuda Dan Olahraga Di Kabupaten Ende Propinsi Nusa Tenggara Timur.}

Dari hasil penelitian diatas menunjukan bahwa menurut terori Edwin Ghiselli (2014 ; 295) mengatakan Setiap lembaga/instansi memiliki tujuan dan cita-cita di dalamnya, sebagai proses untuk mencapai tujuannya, untuk mengoperasikan sebuah lembaga/instansi, dibutuhkan satu kesatuan perangkat yang berhubungan sebagai motor penggerak instansi/lembaga yaitu kepemimpinan, manajemen dan organisasi. Kepemimpinanberasal dari kata pemimpin adalah ilmu/metode yang mengajarkan bagaimana seseorang menjadi sebuah 'mercusuar' dalam sebuah instansi/lembaga yang mampu menjadi patron bagi para bawahannya. Kepemimpinan adalah salah satu bagian yang vital dalam hal mengoperasikan sebuah instansi/lembaga. Sebuah instansi/lembaga harus memiliki pemimpin yang memiliki kriteria yang mencukupi sebagai seorang pemimpin untuk menjalankan roda kegiatan instansi/lembaga secara maksimal sebagai bagian dari proses menuju cita - cita instansi/lembaga.

Untuk menjadi seorang pemimpin yang ideal tidaklah mudah. Beberapa kriteria seorang pemimpin ideal diantaranya adalah bijaksana, arif, cerdas, tangkas, berwawasan luas, berintelektual dan berani. Kriteria menjadi seorang pemimpin yang ideal memang memiliki banyak interpretasi, namun satu hal yang pasti seorang pemimpin yang cakap harus menguasai kecerdasan intelektual, kecerdasan moral dan kecerdasan spiritual yang merupakan elemen utama dan harus dimiliki oleh seorang pemimpin. Seorang pemimpin juga harus memilik intuisi dan psikologis yang peka. Pemimpin yang ideal harus mengetahui sisi kelebihan dan kekurangan instansi/lembaga yang dipimpinnya. Dia memiliki kemampuan untuk mengeksplorasi kelebihan lembaganya dan meminimalisir kekurangannya agar roda kegiatan instansi/lembaga berjalan dengan profesional dan proporsional.

Manajemen adalah seni mengelola sebuah instansi/lembaga untuk mencapai tujuan yang ditetapkan melalui tangan dan kinerja orang lain. Dapat juga dikatakan manajemen adalah ilmu yang mempelajari tentang tata cara mencapai tujuan sebuah instansi/lembaga melalui karya orang lain. Manajemen- 'to manage'merupakan elemen lain yang sangat penting disamping kepemimpinan sebagai alat untuk menjalankan kegiatan sebuah instansi/lembaga. Sebuah instansi/lembaga harus memiliki kerangka rencana strategis sebagai tolok ukur dan landasan kerja sebuah instansi/lembaga agar hasil yang ditetapkan tercapai dengan semaksimal mungkin.

Kerangka rencana kerja strategis yang dibuat harus dibuat sesuai dengan karakteristik organisasi yang dipimpinnya agar program kerja yang dicanangkan sebuah instansi/lembaga sesuai dengan target yang ditetapkan dan tidak membebani instansi/lembaga yang dipimpinnya. Beban pengeluaran yang harus dikeluarkan instansi/lembaga harus sesuai dengan landasan filosofis, teori, model, strategi, taktik, kurikulum, program dan pembiayaan yang telah disusun. Oleh karena itu, dibutuhkan sebuah landasan teori yang kuat sebagai kerangka dasar rencana kerja sebuah instansi/lembaga yang terdiri dari Planning, Organizing, Actuating dan Controlling agar peristiwa Input Proses Outputnya berjalan dengan sebagaimana mestinya . Peristiwa input proses output menjadi sebuah hasil akhir yang sangat menentukan untuk mengukur tingkat keberhasilan dan kegagalan dari sebuah metode manajemen yang diberlakukan.

Ketika hasil akhir dari sebuah instansi/lembaga telah diketahui, Sebuah instansi/lembaga dapat mengukur tingkat 
keberhasilan atau kegagalan yang telah dialami serta menentukan langkah perusahaan kedepannya dengan sebuah alat analisa yang dinamakan analisis S.W.O.T ( Strengths, Weakness, Opportunity, Threatments ). Dengan Analisis S.W.O.T sebuah lembaga/instansi dapat mengetahui posisi lembaga/instansi yang dipimpinnya dari sebuah program kerja yang dibuatnya. Hasil akhir dari sebuah rencana kerja yang dibuat dapat menentukan posisi, tingkat keberhailan dan nilai tawar sebuah instansi/lembaga dikarenakan 'finishing' dan 'results' dari sebuah rencana kerja merupakan cermin dari metode manajemen yang diterapkan sebuah instansi/lembaga. Perkembangan teori manajemen juga mencakup model-model atau teori-teori motivasi yang berbeda-beda yaitu sebagai berikut : (1). Model Tradisional, (2). Model hubungan manusiawi (3). Model sumber daya manusia

Berdasarkan hasil wawancara, dan pendapat para pakar ahli sesuai dengan fakta yang ada dilapangan menunjukan bahwa kepemimpinan di Bidang Pemuda dan olahraga Pada Dinas Pendidikan Pemuda dan Olahraga Kabupaten Ende.pada penelitian saya dan hasil wawancara menunjukan bahwa kepemimpinan sangat berkompoten menjalakan tugasnya dalam meningkatkan olahraga prestasi, kemudian sangat professional dalam mengambil keputusan untuk setiap kegiatan dan pelaksanaan dalam meningkatkan olahraga prestasi, pemimpin yang memberikan motivasi kepada bawahanya,kemudian keputusan yang diambil oleh pemimpin dalam menjalankan tugas dan tanggung jawabnya menjalankan tugas dan kegiatan bedasarkan musyawarah dan kesepakatan bersama jajaranya untuk mengembangkan olahraga prestasi, pemimpin yang sangat terbuka dan transparan yang menyangkut anggaran untuk setiap kegiatan dalam rangka meningkatkan olahraga prestasi, memberikan bentuk penghargaan kepada bawahanya yang berprestasi, untuk mengikuti kegiatan pelatihan olahraga yang ada di luar daerah Kabupaten Ende dalam meningkatkan olahraga berprestasi.

Dari pendapat saya dalam penelitian di Dinas Pendidikan Pemuda dan Olahraga Kabupaten Ende tentang kepemimpinan saya menyimpulkan dan membahas Minor penelitian ini, Kepemimpinan sudah berjalan dengan apa yang menjadi tanggung jawabnya dalam meningkatkan olahraga prestasi. diharapakan disini adalah pemimpinan harus loyal dan transparan dalam hal pemilihan, perekrutan para angggota panitia, pengurus, official, pelatih harus ada pemerataan, sehingga tidak ada kecemburuan sosial dalam meningkatkan olahraga prestasi.

\section{Pelaksanaan Manajemen Olahraga Prestasi Di Dinas Pendidikan Pemuda Dan Olahraga di Kabupaten Ende. \\ Dari hasil penelitian diatas menunjukan} bahwa menurut teori Robert J. Mockler dalam Buku T.Hani Handoko (2013). Dari seluruh rangkaian proses manajemen, pelaksanaan (actuating) merupakan fungsi manajemen yang paling utama. Dalam fungsi perencanaan dan pengorganisasian lebih banyak berhubungan dengan aspek-aspek abstrak proses manajemen, sedangkan fungsi actuating justru lebih menekankan pada kegiatan yang berhubungan langsung dengan orang-orang dalam organisasi. Dalam hal ini, mengemukakan bahwa actuating merupakan usaha menggerakkan anggotaanggota kelompok sedemikian rupa hingga mereka berkeinginan dan berusaha untuk mencapai sasaran perusahaan dan sasaran anggota-anggota perusahaan tersebut oleh karena para anggota itu juga ingin mencapai sasaran-sasaran tersebut.

Dari pengertian di atas, pelaksanaan (actuating) tidak lain merupakan upaya untuk menjadikan perencanaan menjadi kenyataan, dengan melalui berbagai pengarahan dan pemotivasian agar setiap karyawan dapat melaksanakan kegiatan secara optimal sesuai dengan peran, tugas dan tanggung jawabnya. "Actuating merupakan usaha menggerakkan anggota-anggota kelompok sedemikian rupa hingga mereka berkeinginan dan berusaha untuk mencapai sasaran perusahaan dan sasaran anggota-anggota perusahaan tersebut oleh karena para anggota itu juga ingin mencapai sasaran-sasaran tersebut. Jadi actuating adalah usaha menggerakkan seluruh orang yang terkait, untuk secara bersama-sama melaksanakan program kegiatan sesuai dengan bidang masing-masing dengan cara yang terbaik dan benar.

Actuating merupakan fungsi yang paling fundamental dalam manajemen, karena merupakan pengupayaan berbagai jenis tindakan itu sendiri, agar semua anggota kelompok mulai dari tingkat teratas sampai terbawah, berusaha mencapai sasaran organisasi sesuai rencana yang 
telah ditetapkan semula, dengan cara terbaik dan benar. Memang diakui bahwa usaha-usaha perencanaan dan pengorganisasian bersifat vital, tetapi tidak akan ada output kongkrit yang akan dihasilkan sampai kita mengimplementasi aktivitas-aktivitas yang diusahakan dan yang diorganisasi. Untuk maksud itu maka diperlukan tindakan penggerakan (actuating) atau usaha untuk menimbulkan action. Hal yang penting untuk diperhatikan dalam penggerakan (actuating) ini adalah bahwa seorang karyawan akan termotivasi untuk mengerjakan sesuatu jika merasa yakin akan mampu mengerjakan, yakin bahwa pekerjaan tersebut memberikan manfaat bagi dirinya, tidak sedang dibebani oleh problem pribadi atau tugas lain yang lebih penting, atau mendesak, tugas tersebut merupakan kepercayaan bagi yang bersangkutan dan hubungan antar teman dalam organisasi tersebut harmonis.

Dari pengertian di atas, pelaksanaan (actuating) tidak lain merupakan upaya untuk menjadikan perencanaan menjadi kenyataan, dengan melalui berbagai pengarahan dan motivasi agar setiap karyawan dapat melaksanakan kegiatan secara optimal sesuai dengan peran, tugas dan tanggung jawabnya.

Berdasarkan hasil wawancara, dan pendapat para pakar ahli, sesuai dengan fakta yang ada dilapangan menunjukan bahwa di Pengorganisasian yang dilakukan oleh Bidang Pemuda dan olahraga menunjukan bahwa pelaksanaan tugas manajemen pelaksanaan prestasi olahraga di Dinas Pendidikan Pemuda dan Olahraga Kabupaten Ende telah terlaksana dengan baik, meskipun satu dan dua hal lain yang belum terlaksana sesuai dengan rencana. Dalam kegiatan olahraga prestasi dinas pendidikan pemuda dan olahraga mengadakan kejuaraan dalam meningkatkan olahraga prestasi, setiap kegiatan olahraga yang diselenggarakan mendapat respon yang positif dari masyarakat, sekolah untuk meningkatkan olahraga prestasi. Dalam merealisasikan kegiatan para pegawai dilibatkan secara keseluruhan dan setiap kegiatan dilakukan berjalan sesuai manajemen yang direncanakan, semua pegawai melaksanakan fungsinya dengan baik pada bidang keolahragaan dalam meningkatkan olahraga prestasi.

Dari pendapat saya dalam penelitian di Dinas Pendidikan Pemuda dan Olahraga Kabupaten Ende, tentang perencanaan saya menyimpulkan dan membahas minor penelitian ini, dalam segi pelaksanaan olahraga prestasi masih ada kekurangan yaitu persoalan dana keuangan untuk latihan persiapan mengikuti even atau pertandingan, ditambahnya sarana prasarana yang sangat dibutuhkan oleh para atlit untuk meningkatkan olahraga prestasi. Kemudian persiapan sumber daya manusia dalam hal ini pelatih, pembina, instruktur yang profesional agar dapat mewujudkan visi dan misi olahraga prestasi di Kabupaten Ende.

\section{Pengawasan dan Evaluasi Manajemen Olahraga Prestasi Di Dinas Pendidikan Pemuda Dan Olahraga Kabupaten Ende.}

Dari hasil penelitian yang dilakukan di Dinas Pendidikan dan Pemuda dan olahraga Kabupaten Ende dan pendapat para ahli menyatakan. Mengenai pimpinan di bidang Mundora sangat profesional dalam pengambilan keputusan untuk setiap kegiatan dalam meningkatkan olahraga prestasi, pemimpin terbuka dan transparan meyangkut anggaran untuk setiap kegiatan dalam meningkatkan olahraga prestasi, biasanya pimpinan mengambil inisiatif sendiri dan berdasarkan musyawarah dalam meningkatkan olahraga prestasi.

Mengenai pengawasan dan evaluasi, dalam pimpinan biasanya melakukan pemeriksaan dan control terhadap kehadiran para pegawai dalam meningkatkan olahraga prestasi. mengenai perlengkapan sarana prasarana dilingkungan Dispora kami selalu berkoordinasi antara bidang demi meningkatkan olahraga prestasi di kabupaten Ende tercinta. kemudian mengenai kerja sama antara personil dibidang olahraga prestasi kami saling memberikan masukan terkait dengan tugas dan tanggung jawab yang diberikan dalam meningkatkan prestasi olahraga. Setiap minggu kepala bidang memonitoring proses kegiatan yang dilaksanakan oleh pegawai dalam meningkatkan olahraga prestasi dan kemudaian program kerja yang telah dilaksanakan dievaluasi oleh masing - masing seksi untuk meningkatkan olahraga prestasi.

Hasil penelitian menunjukkan bahwa evaluasi dan pengawasan tugas manajemen Dinas Pendidikan Pemuda dan Olahraga belum berjalan secara maksimal. Hal ini dapat dilihar dari beberapa hasil wawancara terhadap beberapa pegawai dan pelatih, guru, official terhadap beberapa hasil penelitian yang dilakukan peneliti. Menunjukan bahwa evaluasi tugas dan fungsi pelaksanaan olahraga prestasi 
belum terakomodasi dengan baik, kurangnya sarana prasarana olahraga prestasi, anggaran khusus untuk perbaikan sarana prasarana yang rusak dan tidak terurus belum terakomodasi. Kemudian anggaran uang pembinaan dan penghargaan kepada atlet, pelatih dan official kurang diperhatikan .anggaran untuk kegiatanan pertandingan atau event yang diikuti tidak sesuai dengan apa yang dibutukan.

Menurut Para ahli Koontz, et. al.(2012). Pengawasan dan Evaluasi diibaratkan sebagai satu keping mata uang yang tidak dapat dipisahkan. Maksudnya, pengawasan tampa Evaluasi maka tidak akan terlaksana dengan baik kerena tidak adanya pedoman yang digunakan dalam pengawasan. Begitu juga pengawasan tampa Evaluasi maka tidak dapat diketahui sampai dimana rencana yang sudah dijalankan, bicara tentang pengawasan dan evaluasi tentu tak lepas dari lembaga atau orang yang melakukan pengawasan dan evaluasi. Dalam melakukan pengawasan dan evaluasi sebuah lembaga atau personal tentunya harus memiliki pengetahuan dan keahlian tertentu yang memadai agar dapat melaksanakan tugas dengan baik sehingga tujuan organisasi dapat tercapai.

Sedangakan beberapa Ahli T.Hani Handoko (2014) menyebutkan bahwa yang dimaksud dengan pengawasan adalah: "Proses pengamatan daripada pelaksanaan seluruh kegiatan organisasi untuk menjamin agar supaya semua pekerjaan yang sedang dilakukan berjalan sesuai dengan rencana yang telah ditentukan sebelumnya." ciri terpenting dari konsep yang dikemukan oleh Siagian (2012) ini adalah bahwa pengawasan hanya dapat diterapkan bagi pekerjaan yang sedang berjalan dan tidak dapat diterapkan untuk, pekerjaan yang sudah selesai dilaksanakan berpendapat tentang pengertian pengawasan ini, ia mengatakan bahwa pengawasan berarti mendeterminasi apa yang dilaksanakan, maksudnya mengevaluasi prestasi kerja dan apabila perlu menerapkan tindakantindakan korektif sehingga hasil pekerjaan sesuai dengan rencana?rencana. Jadi pengawasan dapat dianggap sebagai aktivitas untuk menemukan dan mengoreksi penyimpangan - penyimpangan penting dalam hasil yang dicapai dari aktivitas -aktivitas yang direncanakan.

Koontz, et. al. menyatakan bahwa: “ Pengendalian adalah mengukur dan mengoreksi prestasi kerja bawahan guna memastikan, bahwa tujuan organisasi di semua tingkat dan rencana yang didesain untuk mencapainya, sedang dilaksanakan".lebih tegas mengatakan: Pengendalian adalah segala usaha atau kegiatan untuk menjamin dan mengarahkan agar pekerjaan yang sedang dilaksanakan dapat berjalan sesuai dengan rencana yang telah ditetapkan dan atau hasil yang dikehendaki serta sesuai pula dengan segala ketentuan dan kebijakan yang berlaku.Ditinjau dari segi proses administrasi, pengawasan terdidri dari tiga langkah universal yaitu: Mengukur perbuatan, membandingkan perbuatan dengan standar yang telah ditetapkan Memperbaiki penyimpangan atau kesalahan dengan melakukan tindakan pembetulan.

Hani Handoko (2013) pengawasan menyarankan adanya tujuan dan rencana. Tiada administrator yang bias mlakukan control kecuali jika suatu rencana telah dibuat. Tidak ada cara dengan mana seorang administrator bias memastikan bahwa para bawahannya bekerja kearah tercapainya tujuan yang dikehendaki kecuali jika ia memiliki suatu rencana, betapapun kaburnya rencana itu atau betapa jelas dan lengkapnya serta terkoordinasinya rencana tersebut maka pengawasan administrasi bisa dijalankan.

Ada dua faktor yang menimbulkan kebutuhan akan suatu pengawasan. Pertama, tujuan-tujuan induvidu dengan tujuan-tujuan organisasi sering berbeda. Konsekuensinya ialah bahwa pengawasan perlu untuk menjamin para anggota bekerja karena tujuan organisasi. Alternatifnya ialah untuk menghindari atau menetralisir kegiatan yang serampangan atau kegiatan yang tidak terkendali. Kedua, pengawasan perlu disebabkan adanya penundaan waktu antara saat tujuan dirumuskan dan saat tujuan dicapai. Maka selama jarak waktu ini, yang tidak terduga bias menyebabkan penyimpangan antara hal yang sebenarnya dengan perbuatan yang dikehendaki.

Kata evaluasi berasal dari bahasa Inggris evaluation yang berarti penilaian atau penaksiran.Evaluasi adalah proses penilaian. Penilaian ini bisa menjadi netral, positif atau negatif atau merupakan gabungan dari keduanya. Saat sesuatu dievaluasi biasanya orang yang mengevaluasi mengambil keputusan tentang nilai atau manfaatnya Menurut Curtis, Dan B; Floyd, Evaluasi adalah proses penilaian. Penilaian ini bisa menjadi netral, positif atau negatif atau 
merupakan gabungan dari keduanya. Saat sesuatu dievaluasi biasanya orang yang mengevaluasi mengambil keputusan tentang nilai atau manfaatnya. Kemudian memberikan pendapatnya bahwa evaluasi adalah kegiatan untuk mengumpulkan informasi tentang bekerjanya sesuatu, yang selanjutnya informasi tersebut digunakan untuk menentukan alternatif yang tepat dalam mengambil keputusan. Fungsi utama evaluasi dalam hal ini adalah menyediakan informasi-informasi yang berguna bagi pihak decision maker untuk menentukan kebijakan yang akan diambil berdasarkan evaluasi yang telah dilakukan

$$
\text { Sedangkan }
$$

Worthen

dan Sanders mengakatan evaluasi adalah mencari sesuatu yang berharga (worth). Sesuatu yang berharga tersebut dapat berupa informasi tentang suatu program, produksi serta alternatif prosedur tertentu. Karenanya evaluasi bukan merupakan hal baru dalam kehidupan manusia sebab hal tersebut senantiasa mengiringi kehidupan seseorang. Seorang manusia yang telah mengerjakan suatu hal, pasti akan menilai apakah yang dilakukannya tersebut telah sesuai dengan keinginannya semula.

Berdasarkan hasil wawancara, dan pendapat para pakar ahli sesuai dengan fakta yang ada dilapangan di Dinas Pendidikan Pemuda dan Olahraga Kabupaten Ende, menunjukan bahwa Evaluasi dan pegawasan yang dilakukan oleh Bidang Pemuda dan olahraga Pada Dinas Pendidikan Pemuda dan Olahraga Kabupaten Ende, belum berjalan secara maksimal. Hal ini dapat dilihat dari beberapa hasil wawancara terhadap beberapa pegawai dan pelatih, guru, official terhadap beberapa hasil penelitian yang dilakukan peneliti. menunjukan bahwa evaluasi tugas dan fungsi pelaksanaan olahraga prestasi belum terakomodasi dengan baik, kurangnya sarana prasarana olahraga prestasi, anggaran khusus untuk perbaikan sarana prasarana yang rusak dan tidak terurus belum terakomodasi. Kemudian anggaran uang pembinaan dan penghargaan kepada atlet, pelatih dan official kurang diperhatikan .anggaran untuk kegiatan pertandingan atu even yang diikuti tidak sesuai dengan apa yang dibutukan.

"Dari pendapat saya dalam penelitian di Dinas Pendidikan Pemuda dan Olahraga Kabupaten Ende, tentang Pengawasan dan Evaluasi dengan ini saya menyimpulkan dan membahas minor penelitian ini, dalam segi
Evaluasi dan pengawasan, perlu ditingkatakan lagi disiplin pegawai dalam menjalankan tugas dan tanggung jawabnya, harus meningkatkan sumber daya manusia yaitu adanya latihan untuk para tenaga administrasi, wasit dan pelatih sehingga olahraga prestasi dapat ditingkatakan tahun - tahun yang akan datang."

"Dari hasil penelitian dan pembahasan diatas saya menyimpulkan secara keseluruhan dalam mayor penelitian bahwa dari Perencanaan, Pengorganisasian, Kepemimpinan, Pelaksanaan, Pengawasan dan Evaluasi olahraga prestasi pada Dinas Pendidikan dan Pemuda Olahraga Kabupaten Ende dari pengamatan saya ada dua hal menjadi hambatan dalam proses prestasi olahraga, yaitu dalam organisasi bidang olahraga belum adanya sumberdaya manusia dalam faktor Pembina olahraga,pelatih ,wasit dan pegawai Administasi. kemudian dalam pelaksanaan kurangnya dana, sarana prasarana sehingga dalam persiapan latihan mengikuti event dan pertandingan skala regional tidak maksimal sehingga prestasi olahraga di kabupaten Ende tidak mendapat hasil yang diharapakan."

\section{SIMPULAN DAN SARAN}

Dari pembahasan di atas dapat di ambil beberapa kesimpulan sebagai berikut:

a. Perencanaan yang dilakukan oleh pihak manajemen Bidang olahraga sudah berjalan sesuai dengan tahapan-tahapan proses perencanaan. Hal ini dapat terlihat dengan adanya program-program yang jelas dan sesuai dengan tujuan yang ingin dicapai dengan hasil yang didapat.

b. Pengorganisasian yang dilakukan oleh Bidang Pemuda dan olahraga sudah berjalan sesuai dengan dasar-dasar organisasi. Hal ini dibuktikan dengan adanya struktur organisasi yang jelas dan dibedakan tugas dan kewajibannya.Walaupun pada dasarnya tugas dilakukan bersama-sama antara Kepala Bidang, kepala seksi dan staf pegawai tetapi hal ini tidak menjadi suatu kendala yang serius dalam pelaksanaan olahraga prestasi.

c. Proses Kepemimpinan yang dilakukan manajemen Bidang Pemuda dan Olahraga Kabupaten Ende dilakukan oleh seorang manajer atau ketua. Setiap pengarahan dilakukan dalam rapat kordinasi setiap satutiga bulan sekali untuk membahas program yang akan dilaksanakan dan yang belum 
dilaksanakan guna mencapai tujuan utama manajemen olahraga prestasi.

d. Pelaksanaan yang dilakukan Manajemen Bidang Olahraga Pada Dinas Pendidikan dan Pemuda Olahraga masih ada kendala dalam hal ini Sarana Prasarana, pendanaan, sumber daya manusia yang menghambat pelaksanaan olahraga prestasi yang ada di Kabupaten Ende.

e. Pengawasan/Evaluasi yang dilakukan oleh pihak Dinas Pendidikan Pemuda dan Olahraga kabipaten Ende lewat Bidang Olahraga sudah berjalan sesuai dengan langkah-langkah proses pelaksanaan. Hal ini dibuktikan dengan berjalannya proses pengawasan dengan cara setiap ada kegiatan atau iven Kepala Bidang mengundang para Staf pegawai Official dan Para Pelatih olehraga prestai dapat mengevaluasi kekurangan dan mencapai tujuan yang diharapkan. dan mengupayakan pembenahan dari apa yang dibutuhkan untuk mengembankan olahraga prestasi.

Berdasarkan pembahasan dan kesimpulan di atas penulis memberikan saran-saran untuk Dinas Pendidikan Pemuda dan Olahraga sebagai berikut:

a) Untuk proses Perencanaan manajemen Bidang Olahraga sudah berjalan dengan baik, hendaknya tetap menjaga keeksistensiannya dengan membuat program-program yang lebih kreatif .

b) Dalam struktur organisasi perlu ditambahkanya wakil ketua Sekretaris Kepala Bidang dan Kepala Seksi harus mempunyai sekretaris dan Staf Pegawainya supaya lebih meringankan kinerja dari Kepala Bidang dan Kepala Seksi, karena tugas seorang Kepala sangatlah banyak. Apa bila ada tugas luar. Dengan itu garis koordinasi akan tetap berjalan.

c) Kepemimpinan sudah berjalan dengan apa yang menjadi tanggung jawabnya dalam meningkatkan olahraga prestasi.diharapakan disini adalah pemimpinan harus loyal dan transparan dalam hal pemilihan,perekrutan para angggota panitia,official,pelatih harus pemerataan.

d) Dalam segi Pelaksanaan olahraga prestasi masih ada kekurangan yaitu ditambahnya sarana prasarana yang sangat dibutuhkan oleh para atlit untuk meningkatkan prestasi. ditambahkannya pelatih-pelatih yang profisional agar dapat mewujudkan visi dan misi olahraga di Kabupaten Ende.

e) Dalam hal Evaluasi dan pengawasan ,perlu ditingkatakan lagi disiplin pegawai dalam menjalankan tugas dan tanggung jawabnya, harus meningkatkan sumber daya manusia yaitu ada latihan untuk para wasit dan pelatih sehingga olahraga prestasi dapat ditingkatakan tahun - tahun yang akan datang.

\section{DAFTAR RUJUKAN}

Andi Ikhsan dan Hasmiyati, (2011). Manajemen Pendidikan Jasmani dan Olahraga. Makasar; UNM Makasar

Anwar Pasau, (2012). Pertumbuhan dan Perkembangan Fisik Pendidikan Jasmani,Olahraga, dan Kesehatan; UNM Makasar

Anna Poedjiadi, (2005). Sains Teknologi Masyarakat.Model Pembelajaran Konseptual Bermuatan Nilai; Rosda :Bandung

Apta Mylsidayu, (2015) Ilmu Kepelatihan Dasar ; Alfabeta Bandung

Ahmadi Khoirul dan Amri Sofyan (2010). Proses Pembelajaran Kreatif dan Inovatif dalam Kelas; Prestasi Pustaka Raya; Jakarta

Arikunto Suhasmini, (2014). Evaluasi Program Pendidikan; Bumi Aksara, Jakarta

Arif Tiro, (2011). Penelitian Tesis dan Disertasi,Andira Publisher,Makasar

A.Susanto,(2014). Filsafat Ilmu; Jakarta Bumi Aksara

Dikdik Zafar Sidik, (2013). Mengajar dan Melati Atletik; Bandung Remaja Rosdakarya

Direktorat Olahraga Depertemen Pendidikan dan Kebudayaan, (1996). Pedoman Olahraga Pembinaan: Jakarta

Dini Rosdiana, (2012). Dinamika Olahraga dan Pengembangan Nilai. Bandung; Alfabeta. 
Dini Rosdiana,(2013).Model Pembelajaran Langsung dalam Pendidikan Jasmani dan Kesehatan. Bandung; Alfabeta

DiniRosdiana,(2013).Perencanaan Pembelajaran Dalam Pendidikan Jasmani dan Kesehatan. Bandung; Alfabeta

G.R.Terry dan L.W Rue, (1985).Dasar Dasar Manajemen. Jakarta; Bina Aksara

Harsuki, (2009).Pengantar Manajemen Olahraga. Jakarta;Raja Grafindo Persada.

H.Y.S.Santoso Giriwijoyo dan Dikdik Zafar Sidik, (2012). Ilmu Faal Olahraga (Fisiologi Olahraga); Bandung. Remaja Rosdakarya

H.Muhammadiyah, (2005). Perencanaan Pengajaran Pendidikan Jasmani dan Kesehatan.; UNM. Makasar

Husdarta H.J.S, (2011).Manajemen Pendidikan Jasmani. Bandung; Alfabeta..

Husdarta H.J.S, (2010).Sejarah dan Filsafah Olahraga. Bandung; Alfabeta

Husdarta H.J.S, (2010).Psikologi Olahraga. Bandung; Alfabeta.

Husdarta H.J.S, (2014). Pertumbuhan dan Perkembangan Peserta Didik dalam Olahraga dan kesehatan . Bandung; Alfabeta.

Husdarta H.J.S, (2010).Belajar dan Pembelajaran Pendidikan Jasmani dan Kesehata. Bandung; Alfabeta.

Paturusi Achmad, (2012). Manajemen Pendidikan Jasmani dan Olahraga. Jakarta; Rineka Cipta .

Robert J.Starrt, (2007).Menghadirkan Pemimpin Visioner ; Penerbit Kanisius . Yogyakarta

Komarudin ， (2013).Psikologi Olahraga. Bandung;Remaja Rosdakarya.

Sugiyono, (2015). Metode Penelitian Pendidikan: Pendekatan Kuantitatif,
Kualitatif, dan $\mathrm{R}$ dan $\mathrm{D}$,Alfabeta, Bandung.

Suriasumantri Jujun S, (2009). Filsafat Imu.; Jakarta. Pustaka Sinar Harapan

Sri Minarti, (2011). Manajemen Sekolah, Menegelolah Lembaga Secara Mandiri, Aruzz Media Jogjakarta

Wirasasmita Ricky ,(2014).Ilmu Uraian Olahraga I. Optimalisasi Pengembangan Kemampuan Fisik Melalui Konsepsi Keolahragaan. Bandung; Alfabeta.

Wirasasmita Ricky , (2014). Ilmu Uraian Olahraga II. Optimalisasi Pengembangan Kemampuan Fisik Melalui Konsepsi Keolahragaan. Bandung; Alfabeta.

Widiastuti, (2011). Tes Dan Pengukuran Olahraga. Jakarta ; Bumi Timur Jaya. 